\title{
Constrained Friendship: Rabelais and the Status of Service in Evangelical Humanism
}

\author{
MICHELLE MILLER
}

University of Michigan

En observant comment Rabelais confronte et finalement réconcilie l'amitié de service avec les valeurs humanistes sociales et de libre arbitre, je propose que cette réconciliation représente une prise de position importante en faveur de l'amitié de service en tant que type de relation compatible avec l'idéal humaniste général marquant la culture française de la Renaissance. En soulignant l'insistance de Rabelais sur le fait que le service et de nouvelles formes d'amitié sont en quelque sorte indissociables des sentiments fraternels humanistes, cet article montre que les dilemmes et les bonheurs impliqués dans ces relations nous amènent à revoir notre appréciation du travail culturel accompli grâce aux opérations et échanges de service.

S ervice is surely one of the most pervasive but overlooked categories through which early modern Europeans made sense of their experience. ${ }^{1}$ As a relational idiom, it informed the relations of chatelains and stewards, lawyers and clerks, parents and children, and even mutually back-scratching peers. Prescribing practical tasks, service relations also structured and legitimated a wide range of emotions - the expression of basic human feelings such as helpfulness, need, gratitude, and love.

In this sense, relations represented in terms of service could be understood to designate forms of attachment, affection, and fellowship. Of course, service was not the only relational form through which texts and individuals described these sentiments. The language of friendship was becoming more diverse and omnipresent in early modern literature; texts also deployed notions of adoptive kinship and spiritual parenthood. ${ }^{2}$ Moreover, writings aligned with the new Christian humanism and with Evangelical strains of faith were dramatizing models of love and fellowship in many ways quite distinct from service. These models emphasized the possibility of freedom and gratuity in human affection, sketching relations grounded in charity, love, and a chosen state of parity. At the same time that Evangelical writing was formulating these relational models (centred on notions of caritas and condescendance, to be discussed later), a variety of texts were also rethinking service on its own terms. These writings were gradually investing importance in the premise of servants' 
free will, and were increasingly coming to emphasize servants as will-endowed individuals who did not necessarily symbolize loyalty or group ties.

This essay situates service with respect to these joint developments, the cultural emergence of Evangelical ideals of friendship, and the rethinking of the servant. In the pages to come, I examine the writings of François Rabelais (1494-1553) as works deeply interested in the status of service relative to more generous and genteel relational forms, as well as to Christian humanism overall. It must be admitted that despite the kindly, Erasmian ways of Rabelais's hero Pantagruel—seemingly the quintessential Christian humanist prince - this gentle giant nonetheless takes Panurge on as a servant. The relevant scenes occur in Pantagruel 9 and 15, shortly after the two men's first meeting. In the same breath in which he praises Panurge as a "gentil compagnon," Pantagruel simultaneously saddles him with a livery, marking him as a member of his household and stereotypically as a servant. "Vrayement ... tu es gentil compagnon," he declares, "je te veulx habiller de ma livrée."3

To be sure, there are multiple meanings to this gesture, as well as to the phrase "gentil compagnon." "Gentil" seems to allude to nobility as well as to kindness or good humour. We might perceive such a compliment as an unlikely precursor to a service tie-as something which implicates Pantagruel in the brokerage of a more egalitarian kind of bond. However, nobility (and for that matter, kindness and good humour) were perfectly desirable in servants, especially within royal households (such as Pantagruel's is premised to be), where glorified service roles provided a way of meting out patronage to well-born friends of the family.

"Livrée" and the gesture of having someone clothed in one is likewise an uncertain matter we must take slowly. Social historians remind us that when an early modern superior clothed a subordinate, this often meant an act of hiring. ${ }^{4}$ However, Rabelais uses the term "livrée" in other senses, such as when the giant Grandgousier has a suit of clothes made up for his son. Being dressed in "habillements à sa livrée" surely does not implicate young Gargantua in a service contract; however, it does make the prince visible and instantly accountable as the lofty personage he is, protecting him through social deference, but also prescribing seemly conduct which befits his princely role.

Even if we only take Pantagruel's act in this minimal, non-contractual sense, it is still a gesture of constraint. By making Panurge a visually recognizable member of his household, Pantagruel implicates his friend in a commitment. Visually tied to the prince's household, Panurge is enjoined to give its interests pride of place, and to make his own less important. To be sure, one must take care not to read this constraint in an anachronistic sense-not to implicate Pantagruel and Panurge 
in a class-based labour contract, nor to take what this article may suggest about service as a single or unifying lens through which to read the bond. As readers of the Pantagrueline epics well know, Rabelais tends to multiply and layer the terms through which he describes things, and no less characters' relationships. 5

Nonetheless, Panurge's commitment to the giant is one that he brings up later, as though service were a meaningful and active dimension of his relationship to the prince. ${ }^{6}$ Thus, even if Panurge and the other men in Pantagruel's retinue should be understood as the latter's friends, with the descriptor "domesticques" designating something like "domestic familiars," service is a traditional part of this role, and the act of belonging to a household implies constraining commitment to its interests. ${ }^{7}$

The meaning of this simple juxtaposition - that of humanist friendship and constraint - implies a weighty dilemma, the case of an Evangelico-humanist friend who is not free. Pantagruel of course emphasizes love when he first seeks a bond with Panurge: "je vous ay ja prins en amour si grand" (249). These feelings in some ways suggest that the trickster holds an emotional upper hand over the giant, and that the social inequity of the two characters is somehow evened out. However, insofar as Pantagruel's love also seems to involve an insistent co-presence ("si vous condescendez à mon vouloir, vous ne bougerez jamais de ma compaignie,") it bears witness to a possessive second meaning. Here, we begin to move subtly toward service. Indeed, Panurge's reply to Pantagruel, which echoes the remarks of a Biblical servant in Matthew 8:19, adopts a subordinate posture. Here, Panurge promises to follow through on expectations which he has understood to be in question: "puis qu' il vous plaist me retenir avecques vous, et j'accepte voluntiers l'offre, protestant jamais ne vous laisser, et alissiez vous à tous les diables" (249). While this is clearly a deeply literary scene, and not at all a socially representative example of how a new servant might be brought into a noble retinue, verbal echoes of service (for example, "puisqu' il vous plaist me retenir") deserve to be noticed.

The language of caritas and brotherly love need not exclude the possibility of service. For example, the memoirs of French statesman Henri de Mesmes provide intriguing examples of how texts could use a language of friendship and parity in engaging someone's service. Mesmes claims that Henri III, in trying to secure his service, insisted that "il n'auroit jamais un pain où je n'eusse pas la moitié. Que pouvois-je synon luy obéir?"9 In this respect, we might let service emerge as something active and meaningful in Rabelais's text, taking Pantagruel's phrase "vous ne bougerez de ma compagnie" to mean not only "you will never leave my company," but also "you will never leave my company of fellows, my retinue." 10 
How Rabelais develops these meanings bears importantly on how we understand Pantagruel, his generosity, and his humaneness. Why indeed should a humanist prince and an agent of brotherly love need to situate his friend in his household, an ambiguous sort of tie? What kind of social role is set forth for the domestic familiar? And what, if any, is the represented relation of service friendship to the advancement of Pantagruel's larger Evangelico-humanist projects? Does Rabelais imply that companionate service is somehow less worthy than other forms of friendship - that its element of obligation dominates its meaning and its gifts?

At stake in the unfolding bond of Panurge and Pantagruel is nothing less than the respectability of service as a social form. Between this prince and the most cherished member of his domestic entourage, questions are raised concerning the timeliness and social acceptability of service. Does Rabelais extend to the exchanges and warmth of friendly service the values of civility and modernity that he allies with more open-ended, Evangelical friendship?

To be sure, Panurge does not always strike us as a representative figure who can index readerly or authorial attitudes toward service. Indeed, his satiric exuberance can lead us to dismiss him as droll and anomalous. However, when we recall his role vis-à-vis the giant, Panurge appears quite different, standing as a modest-sized sidekick and an emblem of the human. As Rabelais grants Pantagruel an ever more heroic status (particularly in the shift from the second to the third book), the author increasingly turns to Panurge as the figure who grounds his analysis of specifically human concerns. Dramatizing all the lovely but difficult unions, labours, and human character traits which must not fret his idealized master, Panurge enacts service in ways that gesture toward perceived social problems of the day.

Moreover, the comic nature of Panurge need not push us to understand him as someone who is uniformly made fun of by the text, who cannot be made to raise serious questions about the politics of friendship. Rabelais's irony does not necessarily operate at the expense of Panurge. As Eduardo Saccone suggests in an intriguing article on irony and sprezzatura, irony's triangular structure often works to create fellowship between the reader and the author, who both chuckle in recognizing a third party. ${ }^{11}$ Within this structure, it is not so easy to locate Panurge, who often laughs at himself and seems to enjoy a supra-textual function of commentary. When we recognize Panurge's proximity to both author and reader, it seems hard to dismiss him as merely the third-party butt of the jokes. Contributing to what irony does-namely, unite the reader and author-Panurge warrants a reading as something more than an object of derision. 
As we begin to piece together what that something might be, we must keep various distinct concerns in mind. As I remarked earlier, Panurge is many things to many people. He incarnates some consummately literary functions and roles, yet he also crops up where Rabelais's thought experiment about communitas assumes its most concrete dimension-where it runs into snags with other kinds of human bonds.

As concerns these social roles, it can seem counterintuitive to approach Panurge as a friendly servant when the social category of vassal also presents itself. Pantagruel's gift of the châtellenie of Salmigundia establishes Panurge as his vassal, and this tie's emphasis on honour and reciprocal loyalty in many ways seems to sit better with the gentle giant's kindly ways. The vassalic tie, one might argue, poses no threat to the kind of disinterested brotherly love we usually understand Pantagruel to be offering. Vassalage is a pledge of mutual devotion, and a chosen bond which does not impinge on personal freedom. Or is it? One might as well suggest that marriage is a non-constraining relation because it is sealed with a moment of mutual choice. Given that vassals could not break off from their lords or deny them loyalty without themselves being attacked, it hardly seems appropriate to view them as unconstrained.

In the pages to come, I will not focus on the Pantagruel-Panurge tie as one of vassalage, nor will I consider vassalage as something that excludes or takes precedence over the personal service and household belonging which is also represented between the pair. Though it is certainly worth noting the ways in which Pantagruel's choice of Panurge as a vassal extends his generosity, this generosity hardly nullifies the forms of obligation which vassalage (and service) also imply. Additionally, the fact that vassals enjoyed greater autonomy than servants, and greater status parity with their lords does not dissolve forms of hierarchy between Pantagruel and Panurge. ${ }^{12}$ Accepting that Rabelais allows a certain blurriness between vassals and servants, both for aforementioned reasons of style and for larger historical causes, I would rather set aside the question of terminology and focus instead on the cultural status of Renaissance service. This status bears importantly on the meaning of Panurge and is worth discussing in detail before coming back to Rabelais.

\section{The Changing Status of the Servant}

If the companionate nature of Panurge's service tie appears at times strained or uncertain, this has much to do with shifts in how texts were constructing servants' identities and work. New forms of professionalism, household stewardship, and 
opportunities allied with the acquisition of humanistic knowledge, were changing how domestics and other subordinates could be depicted and understood. ${ }^{13}$ In addition, renewed attention to the writings of St. Paul came to urge for both real and metaphorical, both common- and gentle-born servants a heightened human dignity as compared to past standards. The Pauline Renaissance prescribed mores for service which sought to extend civility, charity, and at least a measure of freedom to persons in subordinate roles. Erasmus (1466/69-1536), whose writings draw heavily on Pauline ideals, turns at one point in his Institution of a Christian Prince (1532) to Paul's letter to Philemon, a text which discusses a servant said to be understood as "the brother of his former master ... once he had been baptized."14

By admiring this switch from service to fraternity, Erasmus situates service as a relational form improper to Christian living, highlighting the transfer of the two men's bond from an unequal and constraining relation of service to a proportionate and supportive model of brotherhood. Expansions on this idea by Erasmus and others went on to make fraternal kindness a general directive for Christian politics, linking oppression by rulers and masters to drastic states of Biblical slavery. Clamouring for non-archaic models that would abandon Old Testament values of obedience and constraint, many early modern Christians (and Evangelicals in particular) sought to encourage a New Testament politics of mutual love, aid, and voluntarism. Writers in this vein prized a social model premised on elevating the humble, or, as François Rigolot has explained with regards to the notion of condescendance, ${ }^{15}$ charitably stooping toward the lowly, both structures of parity which placed little emphasis on exchange. It was with the most emphatic Christian humanism that writers like Giovanni della Casa maligned the harsh treatment of servants as "slaves" and insisted that such behaviour was "not only repugnant to Christian charity and humility, but even that common notion of humanity which is imprinted in every man." ${ }^{16}$

That early modern culture sought to revamp servants' status in these ways should not be taken to mean that their roles were otherwise or previously understood as tremendously lowly. As Alison Sim points out, we read early modern culture anachronistically when we assume that service was considered degrading in the same ways it is today. ${ }^{17}$ Many sixteenth-century servants received their posts as signs of favour, and nearly all derived pride and status from the protection they received from their masters. Some service appointments conferred more honour than others, and some were solely honorific, but even perfunctory roles in low institutions and households held a means of acquiring sway and moving up a social ladder.

Nonetheless, the dependency and expectation of return implicit in service still bore a certain stigma, and it was this which was being eroded, however partially, in 
the era. While this paradigm is not applicable to service at all tiers of early modern society-disgruntled upper-level nobles, for example, came to complain that their military service and their work of princely accompaniment was being increasingly less appreciated, disdained and trivialized as the royal family and its officers consolidated power and destabilized established systems of rewards-many of society's lower-level, less threatening servants were coming to be represented and conceptualized in subtly elevated ways.

\section{Spiritual Slavery and the Emphasis on Will}

Within this elevation, one of the most important developments as concerns the understanding of social relations was the idea that the servant had an individual will and thus a measure of freedom. This notion was religious in derivation, and stemmed from a metaphor which evaluated the human spiritual and moral condition in terms of a state of servility. An umbrella concept, this servility then came to be described in several different forms. One such kind of enslavement came to be identified with Christians' overly literal observance of the Bible, especially the laws of the Old Testament. Renaissance writings ranging from Biblical paraphrases to works of political economy advanced the claim that adherence to Biblical or institutional injunctions in so-called "indifferent matters" was slavish and against man's better nature. Perpetuating this obsequious observance was undesirable, texts argued, insofar as freedom had already been delivered in the form of Christ's liberal teachings, which had enfranchised humanity from "constraining" Old Testament laws, customs, and dietary practices long since left to Jewish worship.

A second and more unnerving kind of spiritual servitude was said to threaten early modern Christendom in the form of sin, which, handed down to humankind involuntarily through the legacy of Adam's fall, risked condemning us to a servile position of moral non-choice. In this context, the metaphor of servitude was widely engaged and widely debated. A famous quarrel between Luther and Erasmus took up the question of whether human will should be considered free or in thrall, with Luther responding to Erasmus's "De libero arbitrio [On the Freedom of the Will]" with his own "De servo arbitrio [On the Bondage of the Will]." Calvin, in his Institutes of the Christian Religion, was even gloomier than Luther about the state of human bondage, describing sin as a "willing servitude" to which mankind consented, but from which humans paradoxically could not free themselves. Sinning "of necessity, but without compulsion," human souls were dependent on grace for their liberating absolution. ${ }^{18}$ Yet in the writings of Erasmus 
and his followers, including Rabelais, Europe could take comfort in the idea that humanity had already been enfranchised. For these writers, Christ's crucifixion was a sufficient and liberating gesture, and had already freed mankind from sin. Thus, a significant current of Erasmian writing came to emphasize freedom, the individual will, and servitude's non-necessity.

More mundane, this-worldly service, such as waiting at table and accompanying lords, could only hold an allusive, formal relationship to the spiritual oppression of sin and superfluous doctrine. Nonetheless, we see that early modern persons clearly linked these two states, taking the spiritual and institutional freedom which Paul and his early modern followers claimed for Christianity as a call for the softening of real world asservissement (subjection). Erasmus, in his Institution of a Christian Prince, makes Christ's liberation of the soul an argument against tyranny, urging rulers not to oppress their real-world subordinates and subjects in the practical exercise of rule. "Since nature created all men free and slavery was imposed upon nature," he writes, “... consider how inappropriate it is for a Christian to acquire mastery over fellow-Christians, whom the laws did not intend to be slaves, and whom Christ redeemed from all slavery" (40). ${ }^{19}$

Erasmus also emphasized humane modes of behaviour toward his own servants, the student-apprentices whom he put to work in his household and whom his letters regularly liken to sons rather than domestics. ${ }^{20}$ Objectively speaking, Erasmus's reservations about servitude did not prevent him from extracting quite menial work from these famuli, assigning them not just secretarial labours such as copying texts and reading out loud, but regular 6o-mile errands from Basel to Besançon to fetch their master's preferred kind of wine, and household tasks such as the preparation of Erasmus's beloved greens with vinegar $(19,40)$. Yet the humanist's financial generosity, his dogged support of former students' careers, and the solicitude he showed toward their moral, familial, and intellectual well-being all point to a more attentive than usual kind of mastery, one which bespeaks an overlap between Erasmus's spiritual politics and his practical behaviour.

At higher social levels too, one can see the new religious values opening up new ground concerning servants' free expression of wants and wills, and continuing the elevation of these figures' perceived capacities and entitlements. For example, it becomes possible to find texts that elevate servants to the point of granting them moral superiority over their lords. Emphatically Protestant memoir writers like Du Plessis Mornay and the Duc de Sully represent themselves through a kind of assertive servant persona, adopting contrarian but upright stances vis-à-vis their spiritually turncoat, sometimes profligate master Henri de Navarre. Richard Strier 
has identified a similar representational code which ennobles certain domestics in Renaissance drama. Strier shows how particular servants in Shakespeare's tragedies enact a kind of "virtuous disobedience," a wilful and decidedly non-servile audacity whereby they shape the moral codes of their superiors, pressing them with what Strier identifies as a new Protestant ethics of supra-social accountability. ${ }^{21}$ Laurie Shannon has written on the related topos of the "harsh counsellor" in varied literature of the same period..$^{22}$ Formulations such as these all articulate the servant as a figure in possession of a will.

\section{Will and Sociability: the Disconnectedness of the Servant}

Despite the high moral tone allotted to such characters at this time, a kind of uncertainty prevails: a roving question about the parameters of these perhaps non-servile servants. How should they be shown to carry themselves, and was there any assurance that a "friendly" core underlay their harsh advice and self-composure? Questions and concerns about sociability indeed hover insistently around figures aligned with the new service. Insofar as civility and social harmony were an essential aim of civic humanism, there was reason to fear that the acknowledgment of servants' will that came along with the movement might dampen the social warmth to which it also aspired. Thus, beyond the basic challenges being posed to service friendship by the valorization of equity, will, and less hierarchical social models like caritas, threats also arose from the question of whether the new, more self-possessed servants might indeed seek friendship at all.

Texts like Thomas More's Utopia (1516) lend plausibility to such fears, rather quickly narrowing in on how the main speaker, Hythloday, positions himself relative to others. We learn that some years prior to the present moment of the dialogue, Hythloday "took service with" or "yoked himself to" ("se adjunxit")23 Amerigo Vespucci, pursuing the sea-faring goals of his own curiosity and will. However, in the unfolding present of the text, Hythloday rather acidly refuses to become an advisor to princes or indeed join up with anyone who would have him renounce living as he pleases. Insisting to Peter Giles that any sort of work for a superior would be "repellent to my spirit," the seaman's behaviour suggests that this new breed of servant can be socially finicky. ${ }^{24}$

La Boétie, in his treatise on servitude, service, and the strangely voluntary nature of man's oppression, also comes to discuss the social implications of the will and its exercise by lowly persons. Published more than a quarter century after each of Rabelais's books, De la servitude volontaire cannot be taken as a text that would 
have influenced the Pantagrueline epics. However, if it was indeed composed as early as Montaigne suggests, it is a near contemporary of the Tiers Livre (1546), and can be taken as an index of writers' larger interest in these questions. With regards to will and sociability, La Boétie famously suggests that free will and self-direction strongly correlate with friendship, declaring that only those who are free and not in forfeiture of their will can experience the true and elective nature of amitié. The claim is striking precisely because it goes against a more workaday understanding of friends' power to influence our choices. Instead of focusing on the way in which friends, like spouses and relatives, press us with claims and opinions, reducing the sphere of what we may do and desire, La Boétie approaches friendship as a perfectly weightless relation, one whose ethos he locates in the spontaneous, free moment of friends' mutual choosing.

Yet insofar as friendship's lived time and politics cannot be expected to maintain the freedom of this singular first moment, La Boétie shows himself inconsistent. At one point taking up perhaps more standard associations about freedom and isolation, the Discours de la servitude volontaire veers into a description of the will-conscious free person as a lonely Ulysses, unmoored from his home and endlessly roaming the world in solitude:

\footnotetext{
There are always a few persons, of better birth than the others, who feel the weight of the yoke ... who are never tamed by subjection and who always, like Ulysses, who on sea and on land never stopped seeking the smoking chimney of his home, cannot endure merely becoming aware of their natural privileges ... not contenting themselves, like the common populace, with the sights in front of them. ${ }^{25}$
}

The temptation, it seems, is to imagine the free person, the servant/subject come to a state of self-recognition and actualized will, as prone to less social involvement, becoming an uprooted hautain who perhaps would like to enjoy human society, but whose version of self determination entails a life adrift on its periphery, more in the manner of Dante's Ulysses than Homer's. One is reminded of La Boétie's citations from Homer at the beginning of the Discours, which shift from describing servitude under several masters, to describing servitude under one, to the blissful prospect of having no master at all. Casting freedom thus, La Boétie effectively depopulates his hypothetical servant-subject's social context. Symbolically distanced from others' rule, the will-conscious servant is imagined to adopt a literal distance from governing persons and relations, indeed from the whole world of rule and law.

Erasmus, despite his frequent emphasis on fellowship and community, at times marks out similar stances of detachment for the servant-ruler he evokes in The Institution of a Christian Prince. To govern humbly and serve the polity, it is said 
that the will-conscious prince should model himself on the human mind, which is "a servant because it is so assiduous in looking after the body's well-being even though it has no need of it" (41). With a proto-Cartesian cleft between mind and body, a divide which is also then implicitly applied to the "body politic" (that famous schematic of rulers' relationship to their subjects), Erasmus's phrase imagines a prince emblematized not by the head but by the mind, a figure who rules and serves the limbs from a whole different plane of reality, lacking all need and floating apart from any good his subjects could bring him. The image of this servant-ruler is stark, to say nothing of lonely.

Yet as Dolora Wojciehowski has argued in her work on early modern theories of will, ${ }^{26}$ Renaissance writers should not be taken to set forth the unnuanced, straw man theories of autonomous subjectivity which poststructuralism often chalks up to them. Attentive reading points to an early modern awareness that human will was mitigated and compromised by a variety of factors; writers did not necessarily privilege views of a stand-alone unbridled subject. ${ }^{27}$ Such reminders help us lend focus to the social ties of the servant as well.

\section{Rabelais: the (Sociable) Choice to Remain with One's Master}

It is with regard to this issue of the will's social embeddedness that Rabelais's treatment of servant friendship becomes especially intriguing. ${ }^{28}$ The seminal work of Edwin Duval has called attention to Panurge's free will as a crucial object of the Tiers Livre's quest and of the epic's message overall. Pointing out the formally central and thematically unifying role of Chapter 25's Delphic injunction that Panurge come to know himself, and that he arrive at this knowledge on his own, Duval makes visible the epic scope granted to the issue of the servant's self-discovery and his entry into self-chosen behaviour. ${ }^{29}$ Duval also indicates that Pantagruel's indirect shepherding of this process should be understood within a practice of caritas, a show of lenient charity and warm fellow feeling. It is because Pantagruel loves Panurge that he wants him to assume greater mastery over himself and to decide on his own about whether or not to marry.

Yet this same loving deference in some ways makes the two protagonists more distant. Joined not only by ties of friendship and charity, but also a master-servant bond, Evangelical friendly deference at times makes Pantagruel and Panurge blunt their roles of service. For example, Pantagruel declines to provide a straight answer when Panurge seeks his "advis" (advice) before marrying, evading a question which is profoundly within his purview as a social superior in the house in which Panurge 
serves. For Panurge, serving and belonging to Pantagruel's house, wearing its livrée, precludes the pursuit of his own household. The trickster's expressed wish to start a family collides head-on with the amico-domestic commitment he has already made, and in this sense, he needs to negotiate with Pantagruel.

The question of servants' marriage indeed made sense to early modern persons as a supra-individual decision; when it was allowed, it was a deal made with the blessing of the master (or else by a late-night desertion of one's post). More specifically, a royal ordonnance promulgated by at least 1567 and very likely a part of legal custom long before required that servants obtain their masters' permission before marrying, on pain of losing their wages. ${ }^{30}$ While Panurge is never established as this kind of servant, nor does Rabelais's fictional kingdom hold a clear relation to France's legal strictures, the ordonnance nonetheless lends wider context to Panurge's question. ${ }^{31}$ To be sure, the seriousness of the trickster's seeming desire for self-rule-for a household of his own-is undermined by his near-simultaneous expression of unruly sexual desires and a renewed dependency on the giant. However, these kinds of internal contradictions are nothing new for Panurge. His hesitation about marriage and request for advice from Pantagruel may seem a sign of lowly indecision, but in a second co-present meaning, it also affirms obedience and regard toward the man he consults as his "Seigneur" (377).

Where does this development leave us with regards to Rabelais's treatment of servants and their nurturance of will? In a culture in which the language and structures of service were an established form for expressing basic needs and attachments, both functional and emotional, the thought of sacrificing this relation, of letting Panurge leave and get married so as to respect his free will, would have been troubling. It is in this context that Rabelais avoids associating the activation of will with drastic autonomy, developing models of conduct which eschew a possible dichotomy between, on the one hand, self-aware, willed behaviour and, on the other hand, social connectedness. Reaffirming an Erasmian and Pauline principle of sociability which otherwise risks getting lost in a quest for the same thinkers' notion of free will, Rabelais illustrates the servant's topical utility as a figure who unites and makes relevant, perhaps more than any other, questions about subjection and the social.

An important example of the epic works' making-sociable of the free-willed servant may be seen in Frère Jan's decision, in Chapter 52 of the first book, to continue to serve Gargantua. Here, Jan turns down an offer to run an abbey so as to continue his "service agréable" to Gargantua. While he presents this choice as one based in part on his weakness of will, which he finds ill-suited to leadership, Frère Jan nonetheless 
asserts such will in rejecting the post. Thus, Jan guards against taking up voluntarism in ways that would require master-servant and amical fracture.

One of Panurge's important deeds in the Tiers Livre mirrors this choice, turning again to a position of staying with his master (while also heightening the complexity of what such adhesion is shown to mean). Insofar as Pantagruel's character is importantly defined by humane, kindly feelings, Panurge - who moves to preserve social connectedness-only extends the younger giant's general manner, exercising what Edwin Duval, Barbara Bowen, and others have described as his elucidating function, his textual work of getting at what Pantagruel means better than the hero sometimes can himself. As Duval explains in The Design of Rabelais's Pantagruel, Panurge holds a role as the hero's comes, a sidekick role intended to explicate and reinforce the hero's identity. "Like most medieval companions," Duval writes, "[Panurge] acts as [a] foil as well as a counterpart, functioning dialectically both to define the hero's character and to bring a particular issue into clear focus." ${ }^{2}$

As concerns the issue of free choice, Panurge's elucidation of the will's compatibility with social union takes shape as an act of pledging, a gesture of piercing his ear at the beginning of the Tiers Livre's seventh chapter. As Mireille Huchon and others inform us, the gesture draws on Biblical precedent, prescriptions in Exodus 21:7 and Deuteronomy 15:12 concerning the proper treatment of servants. The passage relevant to the earring concerns the manumission of slaves who have served for six years; as both sources explain, masters are enjoined to set them free. However, insofar as this release stands first and foremost as a restoration of the slave's individual free will, he is in fact allowed a say in the matter. Departure is offered with no unspoken cost, but a second choice is made available: "if the slave declares, 'I love my master, my wife, and my children; I will not go out a free person,' then his master shall bring him before God" (Exodus 21:5-6). The servant who has experienced or approached his bond not as oppression but as a starting point for other ties and perhaps even for Christian generosity, uses his free will to stay instead of go. The physical mark of this decision is an earring (Exodus 21: 6), a lasting physical token of interpersonal commitment. In Chapter 7 , it is with just such an earring that Panurge appears before his master. ${ }^{33}$

The striking illustration of this gesture and its precedent in the Bible is that self-rule can in fact go in the direction of servile sociability. Taking up free will does not have to mean going free; it can involve a knowing affirmation of the bond one held before. By these standards, the willed contraction of marriage brings a similar entwining of election and human connectedness. So does friendship. The essential point is the deliberate making of a choice. Even if early modern servants 
always technically had a say about whether or not to serve particular masters, the social potential of their will is illustrated most clearly when the case involves a return motivated by love, that conceptual wellspring of Christian freedom, as Panurge's Biblical allusion suggests is here true for him. As the present-day philosopher John Christman suggests, it is the origin - the motivation — of a choice and not its content which best reveals its relation to freedom. ${ }^{34}$

\section{The Choice of Service as a Multiple Embrace}

Moreover, if one continues pondering the Biblical servant's example, one may notice a second layer of significant meaning. The model set forth in Exodus 21 is no ordinary act of voluntary servitude. In piercing his ear through this intertext, Panurge is not merely committing himself to his master in the way in which one might marry a spouse or pledge fealty to a sovereign. Rather, the returning slave's social commitment embraces more than one person, not pledging himself exclusively to his master, but rather, declaring that he loves his master, his wife, and his children, giving himself over to all three in a single unified movement.

This unification of multiple love objects makes important steps toward a politics of properly fellow feeling, eschewing the exclusivizing tendencies which often mark dramatizations of service and friendship. Early modern writers and theologians often struggled with the question of how caritas, man's love of his fellow man, could be conscionably deemed a virtue when it tended to take shape as kindness toward particular individuals rather than toward humanity overall..$^{35}$

Pictoral representations of charity often grapple with this problem of numbers and competition between affective objects. Charity was frequently allegorized as a bare-breasted woman who allowed children to nurse; yet for her two available breasts, representations often beset her with more than two hungry infants. A 1539 emblem for the Lyon Aumône Générale shows "Charité" being climbed upon by an unfortunate trio of children, who tug and grab at her person. ${ }^{36} \mathrm{~A} 1518$ painting by Andrea del Sarto, executed in France and now in the Louvre, expresses a similar tension, with one of the children flanking Lady Charity burying his head in his arms, possibly weeping while another child is fed and a third solicits Charity's attention. Even if these images attempt to deploy a visual rhetoric of abundance, implying that eventually there may be enough nourishing food for all, in their unfolding present, the problem of numbers and excess mouths requires divisive prioritization.

Panurge's earringed pledge of love toward simultaneous multiple objects-his master, future wife, and future children—does not provide a detailed response to this 
problem of numbers, nor does it begin to grapple with how the committed servant and family man might deal with a conflict of interest were one to arise. Such conflicts also plagued female servant-friends, whose role is little explored by Rabelais, but which has been the subject of insightful work by Laura Gowing, and whose dilemmas of household commitment are staged in texts like the Vieilleville memoirs. ${ }^{37}$ Though a writer like Erasmus extended his voice to women in urging a sociable, married version of a holy life, he includes no particular advice about how women might manage the overlap of family and friendly service..$^{38}$ In many ways, then, male and female servants at all social levels may have shared some related concerns.

Panurge seeks to eschew these troubles. In his refusal to dissolve ties-to give up his connection to Pantagruel altogether in favour of a clean slate of nonobligation-Panurge attempts something like a collective embrace. His choice to pierce his ear beckons a peopled life-one with a master, wife, and childrenrejecting the annulment of ties.

It must be said that the arrangement is not shown to be wholly successful at allowing Panurge to distribute himself among all three of his chosen objects of affection. Adopting non-idealized plotlines, Rabelais accords his character's situation genuine seriousness by making it difficult to smooth out. An initial problem which emerges for Panurge involves the potential exclusivity of service and how it conflicts with that typically accorded a wife and legitimate children. Insofar as masters were typically understood to have disposition over their servants' families and sex lives, the trickster's commitment to Pantagruel in some ways pre-empts his simultaneous pledge to his future family.

This politics is undeniably one of constraint, and Lyndal Roper has discussed masters' control over households' sexual and moral economies as a factor which contributed to the taming of the Reformation's initially "revolutionary" spirit. According to Roper, the patriarchal influence of masters and fathers helped reshape the Reformation as a domestic and fundamentally conservative phenomenon, above all in terms of its gender politics. ${ }^{39}$ Such observations should move us to reflect on the underlying nature of Rabelais's drama of ongoing service, what such a plot choice suggests about the larger nature of his Reformation spirit, and how the author's seemingly progressive vision of caritas actually plays out.

For indeed, the Tiers Livre suggests that Panurge's choice to continue his service implies considerable drawbacks and may hinder his chance for legitimate children. Frequently anxious about becoming a cuckold, Panurge is shown to find his fears intensified, perhaps even founded, by his work as a servant who must travel along with his master, thereby leaving his wife unattended. 
Accompanying Pantagruel is indeed the core of Panurge's service, and while this work can seem rather light (above all in the eyes of readers who tend to overlook it altogether) the pledge to accompany Pantagruel everywhere, "à tous les diables," entails sacrifice. ${ }^{\circ}$ Confiding to Frère Jan in Chapter 28 of the third book, Panurge evokes real strain in the obligation he bears toward the giant. ${ }^{41}$ Describing his situation as a double bind between his debt of companionate service and the marriage to which he aspires, Panurge suggests he does not mind continuing to serve Pantagruel, but fears future harm to his marriage. He describes himself thus:

[I'm] still [the] good-humoured companion, as much or more than ever. That's not what I fear. It's not that that gets me. I fear that through some long absence of our king Pantagruel, whom I must perforce accompany, my wife will make me a cuckold.

Gentil compaignon tousjours, autant ou plus que jamais. Je ne crains cela de par le Diable. Ce n'est là où me deult. Je crains que par quelque longue absence de notre roy Pantagruel, au quel force est que je face compaignie, voire allast il à tous les Diables, ma femme me face coqu" (438-39). ${ }^{2}$

Having chosen some twenty chapters before to pierce his ear and declare his continued love and service to the giant, Panurge now begins to perceive the kinds of effects this may entail for the other confederates of his pact. ${ }^{43}$ Rather than painlessly, idealistically co-existing, Pantagruel and the prospective family of Panurge are imagined to stand in tight competition, with Panurge's accompaniment of the giant carrying the trickster away from his wife, thus leaving her prey to outside suitors. ${ }^{44}$ While the Pantagruel-Panurge bond makes an attempt at conceptualizing "staying with one's master" as a synecdoche for a happy, peopled life, the details are more complex.

The result which Panurge comes to fear is a pitting of his own future household against that of his master, an economy of exclusivity and competition which would co-exist with his caritas-like love for Pantagruel. More grievously, perhaps, Panurge's words in the passage above suggest that the voluntary spirit which marked his initial gesture with the earring could languish later on. The phrase "whom I must perforce accompany," "au quel force est que je face compaignie” situates Panurge's companionate service as something he will eventually experience as constraint, an obligation to Pantagruel which retrenches the will that Rabelais's ethics so sacredly prize.

\section{The Ethics of Overlapping Ties and the Status of Service}

By linking Panurge's fears about cuckoldry to his role of companionate service, Rabelais seems to express serious doubts about the compatibility of service with 
the larger aims of Evangelical humanism. However, by examining a final passage from near the end of the Tiers Livre, I would like to suggest that Rabelais pulls back somewhat from this seeming condemnation of service, showing how the messy, multiply-obliged servant may nonetheless inform a humanist ethic of moderation and free will.

In many ways, the problems faced by Panurge seem specific to service, but hold relevance to a large sector of Rabelais's readership, the proponents of the active rather than the contemplative life, the "civic" humanists who applied their learning to professional and familial contexts rather than monastic retreat. ${ }^{45}$ The four books grapple with this life, and place it as the destiny and daily situation of the characters. The philosopher-prince Pantagruel is not wholly free in his choices, but must defer to his father, and later on to the higher interests of his realm. Frère Jan must reconcile his wish to protect his friends to his religious precepts of non-violence. In many ways, Evangelico-humanist writings seem to urge the cultivation of selfrule not so as to create a society of autocrats, but so as to carve out in individuals a self-conscious centre of control which could coordinate multiple and overlapping kinds of allegiance.

In short, Rabelais's valorization of choice becomes gradually legible as the curious opportunity to elect larger forms of obedience. In articulating this paradox, Rabelais makes important conceptual use of Panurge's condition as a free yet hindered servant, and of servants' overlapping commitments in general. Indeed, Pantagruel explicitly uses the figure of the servant in his proffered vision of the balanced life, which appears in Chapter 35 of the Tiers Livre. Here, the giant derides slavish devotion to private cares (including spousal devotion and sexual excess) in favour of certain forms of "public" service: to one's community, to God, and to one's friends (463). This notion of public-private moderation and equity, with freedom and obligation each kept in check, also implies a sexual identity, and prescribes a construction of gender as something both chaste and cavalier, involving both verbal assertiveness and sexual victimization.

Favourably presenting this combination of traits to Panurge (and to the reader) Pantagruel organizes his remarks through an example involving a servant, "une fantesque," a term which derives from the Italian "fantesca," or "maidservant." Here, Rabelais's casting choice of a servant is an important innovation. Of the two known sources for this passage, one (Plutarch) describes the woman in question as a married "Spartan girl" who interacts with her "husband." 46 The other source (Erasmus, in his collected Spartan sayings) merely describes a "Lacæna," a Spartan woman. ${ }^{47}$ By reinventing this personage as a servant, Rabelais seems to make the 
passage especially relevant for Panurge. Moreover, insofar as the fantesque is modeled on a spouse, service is established as a relation that parallels marriage, with the fantesque's unnamed partner in her bond (her master) coming to occupy the structural role in which Plutarch casts a husband.

The content of the passage is as follows: while discussing the thorny question of marriage, Pantagruel offers a remark (in truth an analogy) for Panurge. $\mathrm{He}$ suggests that in order to embrace marriage in a moderate, semi-detached manner, Panurge should try to imitate a particular "fantesque de Sparte" (maidservant from Sparta), who seems to have had a semi-detached take on her service role. This stance is explained through an anecdote. Pantagruel recounts that the fantesque, having been asked "if she had ever had intercourse with a man?" replies in the negative, "never: although men had sometimes had intercourse with her." ${ }^{8}$ Intriguingly, the fantesque does not overturn the basic premise of the question, which assumes that servants are no sexual ingénues (particularly, we know, insofar as they are left vulnerably available to lascivious masters). Leaving this sous-entendu in place, the maidservant acknowledges her state of possession and constraint, both servile and sexual. This constraint is simply part of her condition, and the fantesque's acceptance of this seems to be invoked so as to encourage a similar admission by Panurge. The trickster is pushed to acknowledge his own bondage, both in the marital vows he seeks, and implicitly, in his pre-existing service.

However, in contrast to this constraint, the fantesque also signals her exercise of will and personal freedom. This may be seen in the woman's reported choice of phrasing. Importantly, the fantesque describes her sexual history through a syntax other than that used by the question she was posed. The fantesque speaks not of a series of active failings that have tarnished her virtue, but of events which have happened to her, in which men "avoit affaire à elle." This wilful rephrasing of the question carves out a measure of liberty for the fantesque. It flags distaste for her sexual coercion, and thus marks an independent will to which her sexual aggressors cannot lay claim. More globally, this rhetorical resistance signals a non-conciliatory, non-totalizing attitude toward her role, a kind of detachment like that which is urged for Panurge in marriage. As Pantagruel later explains, men should not let affection for their wives "contaminate that single and supreme affection that man owes to God: [nor] neglect the duties that he naturally owes to his country, to the Republic, and to his friends" (463). 


\section{Conclusion}

Here we see the considerable scope which the Tiers Livre grants to its understanding of the servant. In the Evangelico-humanist ethics which Pantagruel sets forth, the servant's particularly hemmed-in version of freedom becomes the defining measure of scale for private life, while also providing a key model of sexuality and gender. The giant's explanation of how one might moderate one's domestic self in fact relies on the example of a domestic, a figure who is both free-spirited and constrained. To be sure, the example of the fantesque leaves much to be desired. The maidservant remains a sexual victim and we moderns might prefer a tale in which she leaves her abusive master altogether, in which she no longer appears as a fantesque at the moment of speaking. However, by suggesting to Panurge that he, like the fantesque, should construct his sexual honour not in terms of what happens to him (i.e., the men who "avoit affaire à elle," or the wife who may cuckold Panurge) but in terms of his own willed choices, Pantagruel offers a means of reconciling the humanist imperatives of freedom and social connectedness. The giant makes service in all its complexity a relation which informs the prescribed course of the well-governed life.

Loosely reflected then in these readings is the conceptual adaptation of service amid religious and cultural changes, but also the endurance of respect for service as a form of sociability. We as readers may observe this endurance not just in aristocratic-minded writings, noble memoirs which recount the happy receipt of household posts, but in humanist-inflected culture as well, with writers such as Rabelais favourably mulling over service while the issue of obligation works its way through a kind of ideological crisis. Continued valorization for service as a timely and humane relational form has important ramifications for how we understand new religious ideals as manifesting themselves in the household, and how we define the ideals of fellowship and union which pervade Evangelical and humanist discourse. At least in the account Rabelais gives us, friendly service is far from perfect, but it is the fact and not so much the form of social union which matters most. Togetherness appears imperative, even if it takes a livery to help bind it.

\section{Notes}

1. I would like to thank George Hoffmann, Ullrich Langer, Virginia Krause, and several anonymous readers for their feedback on various versions of this article.

2. See for example Ullich Langer, Perfect Friendship: Studies in Literature and Moral Philosophy from Boccaccio to Corneille (Geneva: Droz, 1994), and Alan Bray, The Friend (Chicago, University of Chicago Press, 2003). 
3. The sentence that follows specifies that Pantagruel acts on this desire: "Et le feist vestir galantement selon la mode du temps qui couroit" (Rabelais, Euvres complètes, ed. Mireille Huchon [Paris: Gallimard, 1994], p. 271. All references to Rabelais refer to this edition.) This suggests a commission of clothes done in the royal family colours and in accord with present fashions. The adverb "galantement" is intriguing, and evokes the fact that (at least in later times) liveried male servants were meant to be attractive. For this idea, see Cissie Fairchilds, Domestic Enemies: Servants and Their Masters in Old Regime France (Baltimore: The Johns Hopkins University Press, 1984), p. 32 .

4. See Sara Maza, Servants and Masters in Eighteenth-century France: the Uses of Loyalty (Princeton: Princeton University Press, 1983), p. 174.

5. Oumelbanine Zhiri succinctly writes of "les procédés d'accumulation qui sont une des marques distinctives du style de Rabelais," in L'extase et ses paradoxes: Essai sur la structure narrative du Tiers Livre (Paris: Honoré Champion, 1999), p. 26. However much Pantagruel and Panurge may or may not figure as master and servant, this language must be seen to co-exist with other literary and social roles that Rabelais folds in among the pair. It is thus very far from my wish to set aside what scholars have taken great care to discern about the two protagonists' role as epic friends, alter egos, lord and vassal, and unequal partners in caritas. Instead, I would simply like to consider how a more thorough consideration of service might enrich our understanding of the pair, while also lending new perspective to a basic Rabelaisian problem, namely, Panurge's strange uncertainty about marriage.

6. This is of course not to say that Panurge shows himself to be an adequate servant. As we shall see, he seems to conceptualize his role in terms of merely accompanying his master, rather than performing active work.

7. "Familiers" is a consistent variant for "domesticques" in the third and fourth books.

8. This echoes the words of a scribe who affirms to Jesus, "Master, I will follow you wherever you go." See Huchon, p.1278.

9. Mémoires inédits de Henri de Mesmes, ed. Edouard Fremy (Paris: E. Leroux, 1886), p. 188.

10. See chapter 1 of the Quart Livre for a use of "compaignie" to refer to a princely entourage: "Pantagruel prenent congé du bon Gargantua son pere, icelluy bien priant ... prospere naviguage de son filz, et toute sa compaignie" (537).

11. Eduardo Saccone, "Grazia, Sprezzatura, and Affettazione in Castiglione's Book of the Courtier," Glyph: Textual Studies 5 (1979), pp. 34-54.

12. It is furthermore worth stating that although historical and literary scholarship on service often tends to cluster around seventeenth- and eighteenth-century source material, this by no means suggests that service did not exist in the sixteenth century as a form of sociability, nor that it was at that time overshadowed by vassalic ties. What Roland Mousnier means by person-to-person bonds of "fidélité" could not have existed without service, nor could the maison $d u$ roi and other great households have offered coveted roles (gentilhomme de la chambre, maitre d'hôtel, panetier, échanson, 
etc.) as signs of favour. For more on servants and vassals, see Susan Reynolds, Fiefs and Vassals: The Medieval Evidence Reinterpreted (Oxford: Oxford University Press, 1994), esp. pp. 45-46. Langer, pp. 91-92, brings out the religious seriousness imparted to Panurge's vassalic failing. For a basic social history that includes sixteenthcentury service, see Jean-Pierre Gutton, Domestiques et serviteurs dans la France de l'ancien régime (Paris: Aubier Montaigne, 1981).

13. See, among primary sources, the discussion of royal servants in "Le régime d'ung jeune prince," in Le Nef des princes (1525). Also Charles Chappuzeau, Les Personnes que les roys et princes doivent apeler et choisir pour leurs commensaux, domestiques, serviteurs, Conseillers de leurs maisons, \& Ministres de leurs Estats (Paris: Robert Estienne, 1620), p. 7. Among secondary sources, see Lorna Hutson, The Usurer's Daughter: Male Friendship and Fictions of Women in Sixteenth-Century England (London: Routledge, 1994).

14. Lisa Jardine, ed., Institution of a Christian Prince (Cambridge: Cambridge University Press, 2003), p. 40.

15. François Rigolot, "Tolérance et condescendance dans la littérature française du XVI siècle," Bibliothèque d'humanisme et Renaissance 62.1 (2001), pp. 25-47.

16. “[q]uesto non solamente alla carità, \& humilità Christiana, ma ancho [sic] all'humanità volgare grandemente è cõtrario." Trattato degli uffici comuni tra gli amici superiori \& inferiori (Florence: I Giunti, 1564), p. 280. The English translation comes from The Arts of Grandeur and Submission, trans. Henry Stubbe (London: William Lee, 1665), p. 48.

17. Alison Sim, Masters and Servants in Tudor England (Stroud, England: Sutton Publishing, 2006).

18. Institutes of the Christian Religion, 2 vols., ed. John T. McNeill, trans. Ford Lewis Battles, The Library of Christian Classics (Philadelphia: The Westminster Press, 1960), vol. 1, p. 294.

19. This is not to say that Erasmus was incapable of conceptualizing service in positive terms, merely that he decries particularly slavish modes of behaviour.

20. See Franz Bierlaire, La Familia d'Erasme (Paris: J. Vrin, 1968).

21. "Faithful servants: Shakespeare's praise of disobedience," in The Historical Renaissance: New Essays in Tudor and Stuart Culture, eds. Richard Strier and Heather Dubrow (Chicago: University of Chicago Press, 1988), pp. 104-33.

22. Laurie Shannon, Sovereign Amity: Figures of Friendship in Shakespearean Contexts (Chicago: University of Chicago Press, 2004), 189-219.

23. Thomas More, Complete Works, eds. E. Surtz and J.H. Hexter, 12 vols. (New Haven: Yale University Press, 1963), vol. 4, p. 50.

24. Utopia, trans. and ed. Robert M. Adams (New York: W.W. Norton, 1992), p. 7. While More himself obviously reconciled a career of public service and the expression of decisive personal will (at times against that of his master and sovereign), he seems not to represent this as an easy or obvious negotiation. 
25. “Toujours s'en trouve il quelques-uns, mieux nés que les autres, qui sentent le poids du joug ... qui ne s'apprivoisent jamais de la sujétion et qui toujours, comme Ulysse, qui par mer et par terre cherchait toujours de voir de la fumée de sa case, ne se peuvent tenir d'aviser à leurs naturels privileges ... ne se contentent pas comme le gros populas, de regarder ce qui est devant leurs pieds ...," in Étienne de La Boétie, Discours de la servitude volontaire, ed. Simone Goyard Fabre (Paris: Garnier Flammarion, 1983), p. 151.

26. Dolora Wojciehowski, Old Masters, New Subjects: Early Modern and Postmodern Theories of Will (Stanford: Stanford University Press, 1995), p. 5.

27. For another (more indirect) discussion of the mitigating factors that early modern persons perceived to be caught up in their subjectivity and self-disposition, see Victoria Kahn, Wayward Contracts: the Crisis of Political Obligation in England, 16401674 (Princeton: Princeton University Press, 2004).

28. Ullrich Langer suggests that figurations of will in Rabelais reflect categories and debates present in scholastic philosophy. The irrepresentability he identifies in personal will, be it God's or man's, fits with some of the social unease and evasiveness I will identify surrounding individual choice in these works. See Langer's Divine and Poetic Freedom: Nominalist Theology and Literature in France and Italy (Princeton: Princeton University Press, 1990), pp. 126-48.

29. Edwin Duval, The Design of Rabelais's Tiers Livre de Pantagruel (Geneva: Droz, 1997).

30. "S'ils [les domestiques] se marient pendant le tems de leur service, sans le gré ou conge de leurs Maîtres, ils perdent leurs gages, qui seront appliqués aux pauvres des lieux.” Ordonnance de Charles IX, 1567, reprinted in Pocquet de Livonnière, Règles $d u$ droit français, $6^{\text {th }}$ ed. (Paris: Despilly, 1768), p. 50. Beyond a master's power to deny this permission, or to simply fire servants who married, there also existed indirect forms of discouraging servant marriage. See Kate Mertes, The English Noble Household 1200-160o (Oxford: Oxford University Press, 1988), p. 180.

31. Alcofrybas, the narrator of the first two books, is however identified as having "servy a gaiges" (215). Panurge bears an interesting relation to this character-narrator; see ch. 17 of Pantagruel. It is tempting to suggest that "perfunctory" wage-based servants had to ask permission to marry, while glorified primarily companionate ones would have been exempt from such subjection. However this distinction is fuzzy; royal familiars received wages, and their high birth and favour would have made it almost equally important for them to seek royal approval of their spousal alliances.

32. Edwin Duval, The Design of Rabelais's Pantagruel (New Haven: Yale University Press, 1991), p. 66.

33. Of course, the ear-piercing gesture also functions as a means by which Panurge announces a breakdown of his will via incontinent sexual desires. ("Avoir la puce à l'oreille" was period slang for sexual arousal.) As usual, then, notions of service offer not a definitive but merely an expanded reading of the passage.

34. John Christman, "Liberalism and Individual Positive Freedom," Ethics 101.2 (1991), pp. 343-59. 
35. For more on this problem, see François de Sales, Introduction à la vie devote in Ozuvres, ed. André Ravier and Roger Devos, Bibliothèque de la Pléiade (Paris: Galllimard, 1969), pp. 184-86, and Antoine Hotman's “Deux paradoxes de l'amitié et de l'avarice” (1598), Opuscules françoises des Hotmans (Paris: Veuve Matthieu Guillemot, 1616), p. 115; also, Ullrich Langer's analysis of Hotman in Perfect Friendship, pp. 71-86, and John Bossy, Christianity in the West, 1400-1700 (Oxford: Oxford University Press, 1985), pp. 143-48.

36. See Natalie Zemon Davis, "Poor Relief, Humanism, and Heresy," in Society and Culture in Early Modern France (Stanford: Stanford University Press, 1975), p. 57 and Plate 2.

37. Gowing, “The Politics of Women's Friendship in Early Modern England," in Love, Friendship and Faith in Europe, 1300-1800, ed. Laura Gowing, Michael Hunter, and Miri Rubin (New York: Palgrave Macmillan, 2005), pp. 140-47. Gowing's discussion of how heterosexual marriage constrained women's friendship finds echoes in a scene staged between the Maréchal de Vieilleville's daughter and her friend and mistress, Claude de France, who discourages Vieilleville's marriage on the grounds that it will harm their friendship and nullify Vieilleville's appointment as Claude's "premiere dame d'honneur." See Vincent Carloix, Mémoires de la vie de François de Scépaux, Sire de Vieilleville, ed. Michaud and Poujoulat (Paris: Editeur du commentaire analytique du code civile, 1838), pp. 235-36. It is worth recalling the thorny nature of this source.

38. See for example, “The Girl with No Interest in Marriage," In The Colloquies of Erasmus, trans. Craig R. Thompson (Chicago: University of Chicago Press, 1965).

39. Lyndal Roper, The Holy Household: Women and Morals in Reformation Augsburg (Oxford: Oxford University Press, 1989).

40. Neglecting Pantagruel in battle, Panurge nonetheless adheres to his promise to follow, "protestant jamais ne vous laisser" (249).

41. André Tournon has stressed this chapter. See "Dynamique de la déraison: La symétrie faussée du Tiers Livre du Pantagruel,” Europe: Revue Litteraire Mensuelle 757 (1992), pp. 15-16.

42. I borrow the phrase "whom I must perforce accompany" from Donald Frame.

43. In many ways, Panurge's assumption that his wife will cuckold him makes his readiness to stay with Pantagruel predicated on misogyny.

44. The constraints placed on Panurge's desire for heirs lend further complexity and social context to Carla Freccero's evocation of Panurge as an impediment to paternal succession. See Father Figures: Genealogy and Narrative Structures in Rabelais (Ithaca, NY: Cornell University Press, 1991).

45. For "civic humanism," see Hans Baron, The Crisis of the Early Italian Renaissance: Civic Humanism and Republican Liberty in an Age of Classicism and Tyranny (Princeton: Princeton University Press, 1955). 
46. Plutarch's Advice to the Bride and Groom and A Consolation to His Wife, ed. Sarah Pomeroy (Oxford: Oxford University Press, 1999), p. 7. See Huchon, p. 1430 for the passage's sources.

47. Apophthegmatum ex optimis utriusq (Lyons: Sébastien Gryphe, 1556), p. 152.

48. "si jamais elle avoit eu affaire à hom[m]e?" The fantesque replies "non jamais: bien que les hom[m]es quelques foys avoient eu affaire à elle" (462). 